\title{
The Impact of the COVID-19 Pandemic on the Compliance Level of Annual SPT Reporting for Individual Taxpayers at the Pondok Aren Tax Service Office, South Tangerang City
}

\author{
Ambarwati $^{1}$, Indra Sumarna Sobari ${ }^{2}$, Rudi Kristanto ${ }^{3}$ \\ ${ }^{123}$ Indonesia Institut Ilmu Sosial dan Manajemen STIAMI \\ Jakarta, Indonesia \\ Correspondent: ambaryusuf26@gmail.com ${ }^{1}$, $\underline{\text { indra@ } @ \text { stiami.ac.id }^{2} \text {, } \text { rudikristanto@stiami.ac.id }^{3}}$
}

\begin{tabular}{ll}
\hline Received & : August 08, 2021 \\
Accepted & : August 25, 2021 \\
Published & : October 31, 2021
\end{tabular}

Citation: Ambarwati., Sobari, I.S., Kristanto, R. (2021). The Impact of the COVID-19 Pandemic on the Compliance Level of Annual SPT Reporting for Individual Taxpayers at the Pondok Aren Tax Service Office, South Tangerang City. Ilomata International Journal of Tax \& Accounting 2(4),304-312. https://doi.org/10.52728/ijtc.v2i4.369

\begin{abstract}
Indonesia has recorded a total of 1,626,812 positive cases of covid 19, 44,172 people died, recovered 1,481,449 people (last update: April 22, 2021; data source www.Covid19.go.id). The outbreak of the coronavirus or Covid-19 that hit the whole world, Indonesia was also affected by changes in the economy becoming unstable, causing the wheels of business to be hampered or even some have stopped their activities for the next few days. The impact experienced by all taxpayers throughout the country is affected, at least it is enough to make activities in this country not conducive. The decline in the level of the Indonesian economy experienced a very significant decline. The government's policy in fighting this epidemic must be supported from all aspects and levels of society, in line with the government's policy of the Directorate General of Taxes (DGT) of the Ministry of Finance providing relaxation in the form of simplifying the submission of documents for completing annual notification letters or SPT, in conditions of the Covid-19 pandemic This relaxation is provided for corporate taxpayers and individual taxpayers. The low tax revenue due to the impact of the Covid-19 pandemic is a consequence that the government must accept. This study is to find out whether there is an influence on understanding tax regulations, the method used in this study uses a quantitative method based on tax rates and the principle of justice on mandatory compliance, the impact of the Covid 19 Pandemic disaster on the level of compliance with the annual SPT reporting of individual and corporate taxpayers. The Utilization of Information Technology significantly affects taxpayer compliance.
\end{abstract}

Keywords: Covid 19 Pandemic ; Impact ; SPT Reporting

\section{INTRODUCTION}

The COVID-19 pandemic has affected tax revenues for all countries in the world, this is a challenge for countries that have targeted an increase in tax revenues in the $2021 \mathrm{fiscal}$ year. (Brodeur et al., 2021; Thomson et al., 2021). The government was forced indirectly to correct tax revenue targets in line with the economic crisis that occurred due to the COVID-19 pandemic. (Azad et al., 2021; Tibulca, 2021) Even the government must issue a budget for economic recovery 
to maintain people's purchasing power and prevent an increase in poverty. (Guo \& Shi, 2021; Susanti \& Widajatun, 2021). The government has considered various fiscal policy strategies that support the post-pandemic economic recovery (Lin \& Zhang, 2020) . Tax policy must be designed comprehensively so that the fiscal system can provide a balance of both growth, equity and sustainability, with several main considerations that must be considered by policy makers to formulate optimal tax policies during the COVID-19 pandemic. (Deriu et al., 2021; Lahiri \& Yang, $\underline{2021})$

Tax is one of the main sources of government revenue in carrying out state development. As the largest source of funds in the implementation of the Government and development, the role of tax revenues from year to year will increase in supporting national development, this is reflected in the increase in tax revenue plans. The existence of taxes is expected to improve the welfare of all people's lives. The system adopted in collecting taxes in Indonesia is the Self Assessment System, which is a full trust given to taxpayers to calculate, deposit, and report all their tax obligations. This system is used by taxpayers because they are required to fill out an annual SPT tax return, which means that taxpayers are required to calculate and report their income tax payable without going through a third party or tax authorities. Fiskus plays a role in researching the completeness and correctness of reporting as well as conducting inspections to find out the truth of the material in the taxpayer's report, or this case the Tax Return. In practice, this system can increase acceptance because it is carried out by the system that has been implemented. (Cahyadini et al., 2021)

The strategy carried out by the Direktoral Jenderal Pajak (DJP) amid the Covid-19 Pandemic is to optimize state revenues from the tax sector through the expansion of the tax base and continue to play a role through improving the national economy, by encouraging investment convenience that can improve the national economy. This was taken by the Direktoral Jenderal Pajak by making a breakthrough in Perppu 1/2020 regarding state financial policies and financial system stability for handling the 2019 coronavirus disease (covid-19) pandemic and/or in dealing with threats that endanger the national economy and/or system stability. finance, providing tax facilities in the form of incentives, and facilitating business processes to become IT and user friendly. The submission of the Annual SPT completeness documents in the form of complete financial reports and various required completeness documents by the Direktoral Jenderal Pajak Regulation Number: 02/PJ/2019, no later than 30 June 2020 by using the corrected SPT form (DJP, articles, Your Taxes Help Erase Covid-19). (Susanti \& Widajatun, 2021)

It was recorded that until April 19, 2020, it reached $52.97 \%$ or 9,712,537 taxpayers out of a total of around 18 million taxpayers. Meanwhile, when compared to last year in the same period, the number of taxpayers who reported reached 11,682,289 taxpayers (Media Indonesia, April 22, 2020). Indonesia's economic recovery trend in 2021 is projected to continue with an accelerated vaccination program with an on-track supply of vaccines. Tax revenue until February 2021 reached IDR 181.8 trillion. This achievement represents $12.6 \%$ of this year's tax revenue target. Several tax components grew positively when compared to February last year or the period before the COVID-19 pandemic was enacted. (Realization of APBN 2021, Ministry of Finance). The Ministry of Finance's Direktoral Jenderal Pajak noted that individual income tax $(\mathrm{PPh})$ receipts until the end of February 2021 experienced a contraction or minus 12.51\%. Compared to the same period last year, revenue still grew by $19.76 \%$.PPh receipts will continue to move until the reporting period for the Annual Individual Tax Return (SPT) ends on March 31, 2021. The government also provides an extension of the government-borne Income Tax Article 21 incentive (DJP) until June 2021. (Cahyadini et al., 2021) 
The reporting system carried out by individuals, which often occurs in the field is the misunderstanding of individual taxpayers reporting their SPT returns, mistakes occur such as taxpayers being less careful in calculating the amount of income tax that must be paid. Or underpaid $\mathrm{PPh}$ especially using online services using E-SPT which not all taxpayers can understand. With the tax relaxation carried out by the Direktoral Jenderal Pajak it is hoped that taxpayers can carry out their tax obligations properly and do not delay depositing taxes owed, the taxes paid are very much needed by the state in handling the Covid-19 pandemic.

The problems that will be studied in this research are, how is the level of compliance of individual taxpayers in submitting annual SPT reports during the Covid-19 Pandemic, as well as what efforts and strategies are carried out by the Pondok Aren Tax Service Office, South Tangerang City in increasing tax revenues due to impact of the Covid 19 pandemic.

This study aims to examine the effect that occurs on individual taxpayer compliance with the impact of the Covid 19 Pandemic and the efforts that will be made to achieve an increase in individual taxpayer compliance in reporting SPT Returns during the Covid 19 Pandemic.

The investigation of the coronavirus that causes Covid-19 is still ongoing. Initial information that this virus originated from the Huanan seafood market in Wuhan, China is still conjecture and has not become a certainty. Allegedly since September 2019 Launching SCMP (17/4/2020), the research team from the University of Cambridge, England investigating the origin of the virus has analyzed a large number of strains from around the world and calculated that the start of the outbreak occurred between September 13 and December 7, 2019. The results of the research were published in a scientific journal published in the Proceedings of the National Academy of Sciences (PNAS). The team analyzed the strains using phylogenetic networks, mathematical algorithms that can map the global movement of organisms through mutations in their genes. While the coronavirus strains found in Europe are largely descended from East Asian variants, the journal only examined the first 160 strains collected after late December 2019.

Several institutions predict a weakening of the world economy, including the International Monetary Fund (IMF) which projects the global economy to grow at minus 3\%. The government is wary of the impact of the Covid-19 pandemic, considering that this outbreak only began to spread in Indonesia in the second week of March 2020. Along with the regulations related to Work From Home (WFH) for both the government and private sectors, a slowdown in business activities began at the end of March 2020 which has the potential to reduce domestic deliveries which will then reduce the receipt of Pajak Pertambahan Nilai Dalam Negeri (PPN DN) in April 2020. This condition is likely to continue and contract further in May, considering that in April some regions had implemented Pembatasan Sosial Berskala Besar (PSBB) in several affected areas. In line with the implementation of Work From Home (WFH) and Pembatasan Sosial Berskala Besar (PSBB). The government provides tax facilities in the form of relaxation of Article 29 Individual Income SPT PPh Returns, which has an impact on the not yet optimal realization of Article $29 \mathrm{PPh}$ receipts.

There are a total of 2,004,445 people to date in Indonesia who have been confirmed positive for the Coronavirus that causes Covid-19. So, accumulatively in Indonesia, 1,801,761 patients have recovered and are negative for Covid-19 so far.

The data from several studies carried out above affect the economic conditions throughout the world, as well as the Indonesian economy which is not immune from the impacts caused by the Covid 19 pandemic. The Government's commitment to maintaining the sustainability of state finances to realize the safety and welfare of the community is shown by the Government's efforts 
The Impact of the COVID-19 Pandemic on the Compliance Level of Annual SPT Reporting for Individual Taxpayers at the Pondok Aren Tax Service Office, South Tangerang City

Ambarwati, Sobari, Kristanto

to manage the fiscal as well as possible through optimally increasing state revenues, prudent debt management and continuously making efforts to improve the performance of budget absorption.

The Impact of the Pandemic on the Business World at the layer of turnover below IDR 5 billion was most significantly affected by the percentage of taxpayers who recorded a decline in sales on the SPT period of PPN DN by $88 \%$, which resulted in a decrease in the source of state revenue. The slowdown in economic activity and the contraction of GDP can also be seen from the decline to minus 2\% of state revenue sources in 2020. The 2020 National Economic Recovery budget allocation reached IDR 695.2 trillion with a realization of up to $83 \%$ The budget allocation for UMKM with a ceiling of IDR116.31 trillion with a realization of IDR 112.44 Trillion $(96.6 \%)$ with the aim of the program to support UMKM capital and cash flow during the Covid 19 pandemic in the form of capital assistance either through banks or directly. In 2021 the National Recovery budget will increase to IDR 699.43 Trillion, the budget allocation for UMKM and corporations is IDR 193.74 Trillion with the realization of IDR 41.73 Trillion (21.5\%).

Taxation support for the economy and handling the pandemic to help maintain people's purchasing power. The government provides PPh Article 21 facilities borne by the Government for workers in sectors affected by the pandemic and have an income of no more than IDR 200 million a year.

Utilization of fiscal incentives The 2020 tax has helped maintain business resilience of 464,316 taxpayers in PPh article 21 incentives to increase people's purchasing power 131,889 employers, 1.97 million employees amounting to IDR 1.71 trillion, Incentives to help UMKM PPh Final (PP 23 UMKM) ) for 248,275 UMKM amounting to IDR 0.67 trillion. Continued until May 17, 2021, incentives to increase people's purchasing power on PPh 21 for 89,608 employers amounting to IDR 1.01 trillion and UMKM PPh Final (PP 23 UMKM) for 124,736 UMKM amounting to IDR 0.26 trillion.

\section{METHOD}

This research was conducted using quantitative methods, a process of finding knowledge that uses data in the form of numbers as a tool to analyze information about what you want to know (Kasiram (2008: 149). This study aims to test whether there is an effect on taxpayer compliance. Individuals for the impact of the Covid 19 Pandemic and the efforts that will be made to achieve an increase in individual taxpayer compliance in reporting SPT during the Covid 19 Pandemic. This study also uses secondary data in the form of the 2020 and 2021 RAPBN Budget Realization Reports obtained in PSBB Volume 2 PEN (Tax for Accelerating National Economic Recovery, Ministry of Finance).

Data collection technique The data analyzed in the study used secondary data with dependent and independent variables. The dependent variable is the independence of KPP Pratama Pondok Aren, South Tangerang City in tax revenue with the achievement of the number of taxpayers, and the independent variable is the service and performance of KPP Pratama Pondok Aren, South Tangerang City to taxpayers, about;

1) Government Regulation 23 of 2018 is a government regulation that discusses income tax on income from businesses received by taxpayers who have a certain gross turnover, the government provides a PPh Final rate for UMKM of $0.5 \%$. 
The Impact of the COVID-19 Pandemic on the Compliance Level of Annual SPT Reporting for Individual Taxpayers at the Pondok Aren Tax Service Office, South Tangerang City

Ambarwati, Sobari, Kristanto

2) Government Regulation (Perpu) instead of Law Number 1 of 2020. State financial policies and financial system stability for handling the 2019 coronavirus disease (covid-19) pandemic and/or in dealing with threats that endanger the national economy and/or stability financial system.

3) Ministry of Finance Regulation (PMK) No. 28/PMK.03/2020, which regulates the facilities for Income Tax Articles 21, 22, 23, and PPh 22 for imports from April to September 2020. To provide tax incentives for taxpayers affected by the coronavirus, the relaxation provided is $\mathrm{PPh}$ 21 borne by the government for 6 months for workers with a gross income of not more than 200 million. The absence of PPh 21 deductions that are not deducted is expected to maintain people's purchasing power. (www.kemenkeu.go.id. Pemerintah berikan insentif pajak untuk dukung dunia usaha dan masyarakat selama pandemi COVID-19 20/04/2020)

\section{RESULT AND DISCUSSION}

The data analysis strategy used with a quantitative approach between one strategy and another is mutually reinforcing. The strategy is taken to improve and maintain taxpayer compliance with the impact of the Covid 19 pandemic. Descriptive statistics explain the research variables seen from the amount of data obtained from the KPP Pratama Pondok Aren, South Tangerang City, the results obtained are as follows;

Table 1. Income Tax Article 21 Year 2016 to 2020

\begin{tabular}{lcc}
\hline Year & Number of Individual Taxpayers & Amount of Tax Revenue \\
\hline 2016 & 244.338 & 545.255 .707 .959 \\
\hline 2017 & 261.503 & 635.410 .462 .181 \\
\hline 2018 & 280.567 & 772.084 .813 .373 \\
\hline 2019 & 299.735 & 881.907 .237 .581 \\
\hline 2020 & 312.943 & 858.269 .334 .510 \\
\hline
\end{tabular}

Table 2. Total Taxpayer OP PPh 212016 to 2020

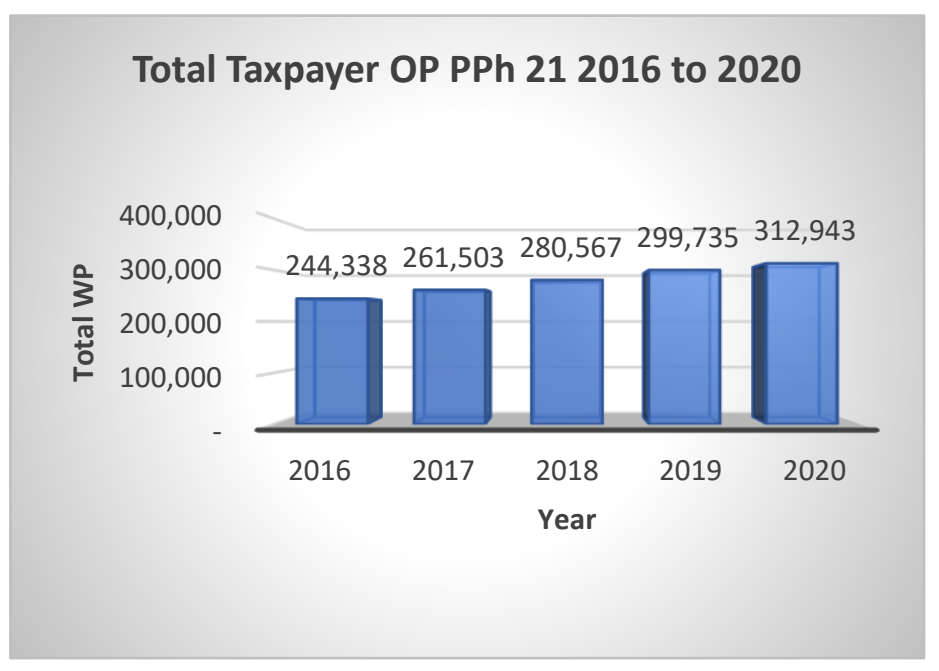


The Impact of the COVID-19 Pandemic on the Compliance Level of Annual SPT Reporting for Individual Taxpayers at the Pondok Aren Tax Service Office, South Tangerang City

Ambarwati, Sobari, Kristanto

Data obtained from the Pondok Aren Pratama Tax Service office, which is presented in the form of a graph, shows that the awareness of Individuals to become taxpayers shows an increase from year to year, as well as the level of compliance made by Individual Taxpayers in reporting annual SPT. Improving the quality and quantity of services is expected to increase satisfaction to taxpayers as customers to increase compliance in the taxation sector. Tax officials make improvements to service quality by increasing taxpayer satisfaction and compliance as well as innovations made to increase awareness to become taxpayers. The tax-friendly UMKM program, which is run by KPP Pratama Pondok Aren, has been running since August 2016 and has received outputs, the results of which can be seen directly that the establishment of the Tax-Friendly UMKM community, whose management structure is not from tax officials, but UMKM figures who become administrator and member of this community.

So that the members of this community feel more comfortable sharing their understanding about business and tax. The Tax-Friendly UMKM Program can increase the level of participation of UMKM in carrying out their rights and obligations in the field of taxation, monitoring and evaluating activities, and the main obstacles faced and how to overcome them. It can be seen that the rate of increase in the number of taxpayers is an average of 4.09 percent a year.

Table 3. Increase in the Number of Individual Taxpayers from 2016 to 2020

\begin{tabular}{cccc}
\hline Year & $\begin{array}{c}\text { Number of Individual } \\
\text { Taxpayers }\end{array}$ & $\begin{array}{c}\text { Increase in } \\
\text { Number of } \mathbf{W P} \\
\text { OP }\end{array}$ & $\mathbf{\%}$ \\
\hline 2016 & 244.338 & 0 & 0 \\
\hline 2017 & 261.503 & 17.165 & 4,00 \\
\hline 2018 & 280.567 & 19.064 & 3,60 \\
\hline 2019 & 299.735 & 19.168 & 3,58 \\
\hline 2020 & 312.943 & 13.208 & 5,19 \\
\hline Amount & 1.399 .086 & 68.605 & 16,37 \\
\hline The average increase per year(\%) & & $\mathbf{4 , 0 9}$ \\
\hline
\end{tabular}

With an average achievement of 4.09 percent per year, it can be seen that the performance of KPP Pratama Pondok Aren in providing awareness to private individuals, including UMKM to become taxpayers who report annual tax returns. During the Covid 19 pandemic between 2019 and 2020, there was an increase in the number of taxpayers 1.61 percent so that it can be interpreted that taxpayer awareness of the importance of fulfilling tax obligations and tax benefits during the pandemic, one of which is to finance the health settlement program in Indonesia.

After the entry of positive cases of COVID-19 in Indonesia was first detected on March 2, 2020. Covid-19 caused an economic contraction in Indonesia. Restriction policies and restrictions on people's mobility have hampered global and domestic economic activities. As a result, GDP contraction hit many countries, including Indonesia, which affected the Indonesian economy, especially the Micro economy, which greatly affected UMKM, and people's purchasing power decreased. Descriptive statistics explain the data obtained from the KPP Pratama Pondok Aren, South Tangerang City, in the receipt of PPh 21 from 2016 to 2020 the results obtained are as follows; 
The Impact of the COVID-19 Pandemic on the Compliance Level of Annual SPT Reporting for Individual Taxpayers at the Pondok Aren Tax Service Office, South Tangerang City

Ambarwati, Sobari, Kristanto

Table 4. Income PPh 21 years 2016 to 2020

\begin{tabular}{cc}
\hline Year & Total Income PPh 21 \\
\hline 2016 & 545.255 .707 .959 \\
\hline 2017 & 635.410 .462 .181 \\
\hline 2018 & 772.084 .813 .373 \\
\hline 2019 & 881.907 .237 .581 \\
\hline 2020 & 858.269 .334 .510 \\
\hline
\end{tabular}

Table 5. Income PPh 21 years 2016 to 2020

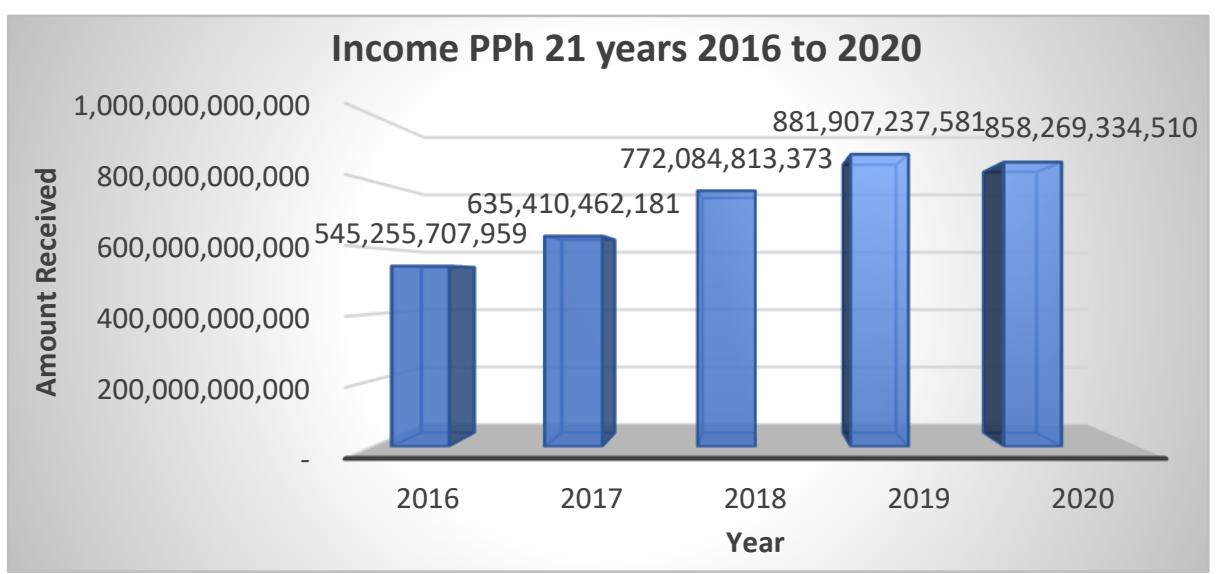

From the data obtained in tax revenue which is illustrated with a graph, there is an increase every year from 2016 to 2018 the efforts made are seen to increase tax revenue by running an innovation program with UMKM, independence by KPP Pratama Pondok Aren to increase tax revenue with the program - program done. Government Regulation 23 of 2018 is a government regulation that discusses income tax on income from businesses received by taxpayers who have a certain gross turnover, the government provides a PPh Final rate for UMKM of $0.5 \%$ which can be an element that affects the increase in income from PPh 21.

Table 6. Increase and decrease in Income PPh 21 from 2016 to 2020

\begin{tabular}{crrr}
\hline Year & Amount & $\begin{array}{c}\text { Increase and decrease in } \\
\text { Revenue PPh21 }\end{array}$ & $\mathbf{\%}$ \\
\hline 2016 & 545.255 .707 .959 & & \\
\hline 2017 & 635.410 .462 .181 & 90.154 .754 .222 & 3,73 \\
\hline 2018 & 772.084 .813 .373 & 136.674 .351 .192 & 2,46 \\
\hline 2019 & 881.907 .237 .581 & 109.822 .424 .208 & 3,07 \\
\hline 2020 & 858.269 .334 .510 & -23.637 .903 .071 & 0,97 \\
\hline Total & $\mathbf{3 . 6 9 2 . 9 2 7 . 5 5 5 . 6 0 4}$ & $\mathbf{3 1 3 . 0 1 3 . 6 2 6 . 5 5 1}$ & \\
\hline
\end{tabular}

From the statistical data above, it can be seen that there was an increase in tax revenues from 2016 to 2019 with a total percentage of 9.26 and an average for 3 years of $3.09 \%$. In the period before the Covid 19 pandemic, there was an increase in tax revenue by reaching the amount of IDR $2,834,658,221,094$,- with an increased rate of IDR 336,651,529,622,- it can be interpreted that the level of compliance of individual taxpayers in paying and reporting the annual SPT can still run 
The Impact of the COVID-19 Pandemic on the Compliance Level of Annual SPT Reporting for Individual Taxpayers at the Pondok Aren Tax Service Office, South Tangerang City

Ambarwati, Sobari, Kristanto

well. In 2019 to 2020 the decline in income from PPh 21 was IDR 23,637,903,071,- percentage value $0.97 \%$.

Government Regulation instead of Law (Perpu) Number 1 of 2020. State financial policies and financial system stability for handling the 2019 coronavirus disease (covid-19) pandemic and/or in the face of threats that endanger the national economy and/or financial system stability, and Ministry of Finance Regulation (PMK) No. 28/PMK.03/2020, which among others regulates the Article 21 Income Tax facility and the provision of tax incentives for taxpayers affected by the coronavirus, the relaxation provided is PPh 21 borne by the Government for 6 months for workers with a gross income of not more than 200 million. The absence of PPh 21 deductions that are not deducted is expected to maintain people's purchasing power. (www.kemenkeu.go.id. Pemerintah berikan insentif pajak untuk dukung dunia usaha dan masyarakat selama pandemi COVID-19 20/04/2020). So that the efforts made by the government in the program to support UMKM capital and cash flow during the pandemic are in the form of capital assistance either through banks or directly.

The decline in PPh21 Revenue in 2020 by $0.97 \%$ that occurred at the Pondok Aren KPP Pratama was the impact of the Covid-19 Pandemic, with the tax relaxation, taxpayers were still reporting and paying annual SPT. Relaxation is well implemented. Even though there was a decrease in income from PPh 21, with the addition of the number of taxpayers with a decrease in taxpayer income due to the impact of the Covid-19 Pandemic.

\section{CONCLUSION}

Based on the results of research and discussion on the Effect of the Impact of the Covid 19 Pandemic on the Compliance Level of Individual Taxpayer Annual Tax Returns at the Pondok Aren Tax Service Office, South Tangerang City, it can be concluded that understanding of regulations and tax benefits has a positive effect on individual taxpayer compliance. . With the policy from the government in tax relaxation during the Covid-19 Pandemic and the benefits obtained from this policy, taxpayers continue to comply with annual SPT reporting even though there is a decline in PPh 21 revenue that occurred in 2020 due to a decrease in people's income and purchasing power.

Based on the results of the research that has been submitted, the authors suggest the following; first, to further improve innovation more consistently to involve the public in general in the pioneering of systematic Annual SPT by approaching online counseling or seminars on how to make good use of the policies provided by the government during the Covid 19 Pandemic. Second, to provide support to UMKM in increasing Turnover by preparing cash flow and financial reports which are very important for reporting the Annual SPT. Third, tax policies and treatment are continuously implemented by involving all levels of society. 
The Impact of the COVID-19 Pandemic on the Compliance Level of Annual SPT Reporting for Individual Taxpayers at the Pondok Aren Tax Service Office, South Tangerang City

Ambarwati, Sobari, Kristanto

\section{REFERENCE}

Azad, N. F., Serletis, A., \& Xu, L. (2021). Covid-19 and monetary-fiscal policy interactions in Canada. The Quarterly Review of Economics and Finance, 81, 376-384. https://doi.org/10.1016/j.qref.2021.06.009

Brodeur, M., Audette-Chapdelaine, S., Savard, A.-C., \& Kairouz, S. (2021). Gambling and the COVID-19 pandemic: A scoping review. Progress in Neuro-Psychopharmacology and Biological Psychiatry, 111, 110389. https://doi.org/10.1016/j.pnpbp.2021.110389

Cahyadini, A., Dewi, S., Sugiharti, D. K., \& Muttaqin, Z. (2021). Direct Tax for Digital Platform During the COVID-19 Pandemic: Study in Indonesia. Journal of Southwest Jiaotong University, 56(2), 271-280. https://doi.org/10.35741/issn.0258-2724.56.2.22

Deriu, S., Cassar, I. P., Pretaroli, R., \& Socci, C. (2021). The economic impact of Covid-19 pandemic in Sardinia. Research in Transportation Economics, 101090. https://doi.org/10.1016/j.retrec.2021.101090

Guo, Y. M., \& Shi, Y. R. (2021). Impact of the VAT reduction policy on local fiscal pressure in China in light of the COVID-19 pandemic: A measurement based on a computable general equilibrium model. Economic Analysis and Policy, 69, 253-264. https://doi.org/10.1016/j.eap.2020.12.010

Lahiri, K., \& Yang, C. (2021). Boosting tax revenues with mixed-frequency data in the aftermath of COVID-19: The case of New York. International Journal of Forecasting. https://doi.org/10.1016/j.ijforecast.2021.10.005

Lin, B. X., \& Zhang, Y. Y. (2020). Impact of the COVID-19 pandemic on agricultural exports. Journal of Integrative Agriculture, 19(12), 2937-2945. https://doi.org/10.1016/S20953119(20)63430-X

Susanti, N., \& Widajatun, V. W. (2021). MSMEs Understanding of Taxation During the COVID19 Pandemic. Journal of Innovation and Community Engagement, 2(1), 35-46. https://doi.org/10.28932/jice.v2i1.3689

Thomson, S., García-Ramírez, J. A., Akkazieva, B., Habicht, T., Cylus, J., \& Evetovits, T. (2021). How resilient is health financing policy in Europe to economic shocks? Evidence from the first year of the COVID-19 pandemic and the 2008 global financial crisis. Health Policy. https://doi.org/10.1016/j.healthpol.2021.11.002

Tibulca, I.-L. (2021). The impact of the COVID-19 pandemic on tax revenues in the EU. Economic Research-Ekonomska Istrą̌ivanja, 1-18. https://doi.org/10.1080/1331677X.2021.1954967 